\title{
Tobacco companies win round in health battle
}

\section{- Smokers warned on packages \\ Anti-smoking campaigns continue}

Washington

IN a decision hailed by tobacco companies and damned by anti-smoking forces, a US appeals court in Boston last week ruled that cigarette manufacturers cannot be sued for damages from smoking on the grounds that they failed to warn consumers of the potential hazards. Since 1965, a warning label has appeared on cigarette packages identifying smoking as a potentially unsafe activity.

The decision arose out of a \$3-million suit brought by the heirs of Joseph Palmer against the Ligget \& Myers Tobacco Co. of Durham, North Carolina. Palmer, a heavy smoker, died of lung cancer seven years ago. A lower court ruled in Palmer's favour, but the three-judge appeals court has unanimously reversed that decision.

This is not the first time courts have ruled that consumers are adequately warned about the dangers of smoking by the package labelling. Earlier last month, an appeals court in Atlanta made a similar decision in favour of the American Brands Co., as did a court in Philadelphia last year. The Philadelphia case was appealed to the Supreme Court, which declined to hear the appeal.

The Federal Cigarette Labeling and Advertising Act of 1965 required that cigarette packages contain the warning that smoking may be hazardous to health. In 1984, that message was changed to four more-specific warnings that change every three months during the year.

Opponents of smoking have argued that although tobacco companies comply with

SURGEON GENERAL'SWARNING: Quitting Smoking Now Greatly Reduces Serious Risks to Your Health.

the letter of the law by placing the messages on cigarette packages and advertising, their promotional campaigns convey the impression that smoking is glamorous rather than risky.

There are currently some 125 lawsuits pending against tobacco companies, seeking damages through product liability. A spokeswoman for Ligget \& Myers says the Boston ruling will limit the scope of claims that can be brought. But according to Richard Daynard, a law professor at Northeastern University and chairman of the Tobacco Products Liability Project, there are many other avenues that litigants may pursue.

Plaintiffs can attempt to prove that cigarettes are an unreasonably dangerous product, and that their risks exceed their benefits. Failure to list potentially hazardous ingredients - such as inorganic fibres like asbestos that may cause health problems - may also make tobacco companies liable for damages. Daynard also points out that many smokers now suffering health problems began smoking before 1965 when the warnings first appeared.

SURGEON GENERAL'S WARNING: Smoking

Causes Lung Cancer, Heart Disease,

Emphysema, And May Complicate Pregnancy.

The percentage of people smoking in the United States has been declining since the mid-1960s. Figures from the National Center for Health Statistics show that in $1965,52.4$ per cent of men over 20 and 34.1 per cent of women over 20 were smokers. In 1985, those figures had dropped to approximately 32 and 27 per cent respectively.

The National Cancer Institute (NCI) has identified a decrease in smoking as one of the key steps towards the goal of reducing cancer mortality by 50 per cent by the year 2000 . According to Joseph Cullen, deputy director of cancer prevention and control at NCI, smoking is associated with some 30 per cent of all cancers.

As a biomedical research agency, NCI is prevented from lobbying directly for a smoking ban. But NCI is involved in clinical trials to identify effective approaches for reducing the frequency of smoking. Self-help, intervention by doctors or dentists, and media campaigns are all part of the constellation of programmes that Cullen believes have had an impact on 10 million people in 25 states. The next stage in NCI's plans is to establish regional coalitions to implement the tools NCI is developing to help people stop smoking.

Cullen worries that although smoking has been declining steadily, it will become harder to get people to kick the habit as reduction efforts get closer to a hard-core of chronic smokers. NCI has just launched a large-scale clinical trial on the health effects of heavy smoking (greater than 25 cigarettes per day) as part of an effort to find effective programmes to help heavy smokers to quit.

The other concern for anti-smoking forces is the growing popularity of smoking among poor and minority populations. Cullen says if things do not change, people in these populations will account for the largest numbers of cancer deaths.

Joseph Palca
Sulphur emissions cut

THE first binding international treaty on air pollution comes into effect this week. Under the Convention on Long-range Transboundary Air Pollution, it obliges 16 ratifying countries to cut back their sulphur emissions by at least 30 per cent on 1980 levels.

The United Nations Economic Commission for Europe (ECE) says ten countries have already achieved the 30 per cent reduction target, but these cutbacks have been partly offset by emission trends in other countries. Overall emissions of sulphur dioxide in Europe have fallen from $\mathbf{5 1 . 3}$ million tonnes in 1980 to 44.7 million in 1985. Data for North America show a decline from 27.8 to $\mathbf{2 4 . 5}$ million tonnes between 1980 and 1983. The ECE says further international efforts are needed to reduce emissions and decrease acid precipitation.

The implementation of the 30 per cent reduction is supervised by the Cooperative Programme for Monitoring and Evaluation of the Long-range Transmission of Air Pollutants in Europe, through of 90 monitoring stations in $\mathbf{2 4}$ countries.

K.J.

\section{Supernova X-rays?}

The Australian space facility at Woomera, inactive since 1979, revived on 25 August with the launch of a West German X-ray telescope aboard a Skylark rocket. The brief flight, after which the telescope was retrieved and returned to West Germany, went ahead after protests from the local aborigine population had been overcome (see Nature 328, 104; 1987).

The instrument observed the recent supernova SN1987a in the Large Magellanic Cloud and preliminary data, indicating only weak X-ray emission from the supernova remnant, are now being analysed at the Max Planck Institute for Extraterrestrial Physics at Garching, near Munich. Joachim Trümper, director of the institute, hopes for continued collaboration, the next event perhaps being the launch of another X-ray telescope in 1988 to observe later stages of the expansion of the supernova remnant.

\section{Shuttle test delay}

Plans to resume space shuttle launches in June 1988 were temporarily derailed on 27 August, when a series of technical hitches delayed and then postponed for two days the scheduled first test at Morton Thiokol's Wasatch Facility in Utah of the redesigned shuttle solid-fuel booster.

On the first firing atttempt, a hose broke; on the second, there was a computer failure.

D.L.

\section{Launcher a success}

JAPAN's space programme is progressing. Last Thursday the experimental three-stage H1 rocket successfully launched a satellite into geostationary orbit. 